Submission: 11-12-2017; Revision: 21-10-2018; Published: 25-12-2018

Available online at: http://e-journal.upstegal.ac.id/index.php/jip

Doi: http://dx.doi.org/10.24905/jip.v3i2.830

\title{
Implementasi Kebijakan Kemitraan Tata Kelola Hutan Sebagai Resolusi Konflik di Register 45 Mesuji Lampung
}

\author{
Andrialius Feraera') *, Nandang Alamsah D $^{2)}$, Neneng Yani Yuningsih ${ }^{3)}$ \\ 1,2,3 Program Pascasarjana Ilmu Pemerintahan, Universitas Padjadjaran Bandung Jawa Barat. \\ * Korespondensi Penulis. E-mail: andrialius15001@mail.unpad.ac.id Telp: +6285348308266
}

\begin{abstract}
Abstrak
Hutan Register 45 Kabupaten Mesuji telah mengalami perambahan oleh masyarakat dan dialihfungsikan menjadi lahan perkebunan dan pemukiman sehingga menimbulkan konflik. Pada tahun 2015, terjalin kemitraan pengelolaan hutan antara Pemerintah, PT. Silva dan masyarakat perambah. Dalam Pelaksanaanya, kemitraan ini tidak berjalan sebagaimana yang diharapkan (Implementation Gap). Atas dasar tersebut penelitian ini bertujuan untuk melihat pelaksanaan kemitraan dan faktor yang mendukung dan menghambat kebijakan kemitraan pengelolaan Hutan Register 45. Metode yang digunakan adalah kualitatif studi kasus. Berdasarkan penelitian, realisasi kemitraan pengelolaan hutan ini sangat jauh dari target yang telah ditetapkan. Faktor yang mendukung kemitraan pengelolaan hutan ini dalam dimensi struktur manajemen program adalah dipergunakannya teori kausal dan ketersediaan dana. Faktor penghambatnya adalah kejelasan dan konsistensi tujuan, dasar hukum, keterpaduan pelaksana kebijakan dan keterbukaan. Sementara itu, dimensi faktor di luar peraturan menjadi faktor yang paling dominan dalam menghambat kebijakan ini meliputi kondisi sosial dan keamanan, dukungan publik, sikap masyarakat dan komitmen pejabat pelaksana.
\end{abstract}

Kata Kunci: Kebijakan; Resolusi Konflik; Tata Kelola Hutan

\section{Implementation of Forest Governance Partnership Policy as Conflict Resolution on Register 45, Mesuji Lampung \\ Abstract}

Forest Area Register 45 in Mesuji Distrcit has been encroached by the local people and the function of this forest area is converted into plantation and settlement that cause conflict. Eventually, in 2015, partnership in forest management was initiated between the Government, PT Silva Inhutani and the squatters involved in the farmers group. Considering the aforementioned issue, the present study investigated the partnership implementation and factors contributing and inhibiting the policy of forest management partnership Register 45. The concept of policy implementation that is used this research is to use the concepts of Sabatier and Mazmania. The method used is a qualitative case study. Based on research in its implementation, the partnership has not shown well performance or an implementation gap has happened. Factors which are in support of this partnership, is the funding availability and use of theory. While the inhibiting factors are as among others, clear and consitent objectives, legal framework, the cohesiveness, and openness towards outside parties, namely social and security, public support, public's attitude, and the commitment of all organizers.

Key Word: Public Policy; Conflict Resolution; Forest Governance 


\section{Jurnal Ilmu Pemerintahan: Kajian Ilmu Pemerintahan dan Politik Daerah, 3 (2), Oktober 2018 - 182 \\ Andrialius Feraera1) *, Nandang Alamsah ${ }^{2)}$, Neneng Yani Yuningsih ${ }^{3)}$}

\section{PENDAHULUAN}

Hutan merupakan salah satu sumber daya alam yang memiliki nilai ekonomi yang sangat tinggi untuk meningkatkan pertumbuhan ekonomi. di sisi lain, hutan juga berpotensi menimbulkan konflik dalam hal pengelolaannya. Krisis ekonomi yang dialami Indonesia pada tahun 1990an menyebabkan banyak perusahaan terguncang dan tidak menggarap tanah perusahaan. Krisis ekonomi ini membuat masyarakat berani untuk merambah dan menggarap tanah-tanah perusahaan yang diterlantarkan tidak terkecuali kawasan Register 45 Kabupaten Mesuji (Wahab, 2013: 219).

Kawasan Register 45 Kabupaten Mesuji Lampung memiliki luas sebesar 43.100 Ha dan telah mengalami perambahan oleh masyarakat sebesar 30.562 Ha (72\%). Perambahan yang dilakukan masyarakat di kawasan Register 45 akhirnya menimbulkan konflik antara masyarakat dan perusahaan dalam hal ini PT. Silva Inhutani sebagai pemegang hak guna usaha (HGU).

Menyikapi hal tersebut, pada tahun 2014 Kementerian Kehutanan melalui Dinas Kehutanan Kabupaten Mesuji dan Pemerintah Kabupaten Mesuji menawarkan solusi atas konflik pengelolaan hutan berupa kebijakan kemitraan pengelolaan hutan dan terjalinlah kemitraan antara Perusahaan dan Masyarakat pada tahun 2015.

Kebijakan kemitraan pengelolaan hutan ini mengacu pada Peraturan Menteri Kehutanan Nomor P.39/ Menhut-II/2013 tentang Pemberdayaan
Masyarakat Setempat Melalui Kemitraan Kehutanan. Kemitraan pengelolaan hutan ini merupakan kerja sama antara masyarakat setempat dengan pemegang izin pemanfaatan hutan atau pengelola hutan, pemegang izin usaha industri primer hasil hutan, dan/atau kesatuan pengelolaan hutan dalam pengembangan kapasitas dan pemberian akses, dengan prinsip kesetaraan dan saling menguntungkan.

Salah satu poin kemitraan adalah pemerintah mengubah kebijakan pengelolaan hutan yang diserahkan kepada masyarakat dari 5\% menjadi $20 \%$ atau 8620 Ha dari 43.100 Ha dan setiap keluarga akan mendapatkan maksimal 2 Ha. MOU kemitraan pengelolaan hutan ini juga mengatur tentang tugas dan kewajiban semua pihak yaitu adalah PT. Silva Inhutani mempunyai tugas dan tanggung jawab mengatur dan menentukan lahan yang akan ditanami pokok kayu dan tanaman semusim serta menyediakan bibit yang berkualitas. Kedua, PT. Silva Inhutani juga menyediakan modal untuk budidaya tanaman dan harus mengatur serta memberikan bimbingan teknis kepada kelompok tani yang bermitra. Terakhir, PT. Silva Inhutani harus membeli semua hasil produksi tanaman pokok kayu dan tanaman semusim dengan harga pasar

Bagi kelompok masyarakat yang bermitra, berdasarkan pada MOU kemitraan masyarakat wajib pertama, membentuk kelompok dan bertanggung jawab terhadap anggota kelompok yang dilibatkan dalam perjanjian. Kedua, menanam pokok kayu dan tanaman semusim yang telah disepakati. Ketiga, 


\section{Jurnal Ilmu Pemerintahan: Kajian Ilmu Pemerintahan dan Politik Daerah, 3 (2), Oktober 2018 - 183 \\ Andrialius Feraera ${ }^{1)}$ *, Nandang Alamsah ${ }^{2}$ ), Neneng Yani Yuningsih ${ }^{3)}$}

wajib melakukan penyulaman terhadap tanaman yang mati atas biaya kelompok masyarakat jika disebabkan oleh kesalahan kelompok masyarakat setelah dilakukan penelitian oleh Kepolisian dan PT. Silva Inhutani. Terakhir, kelompok masyarakat yang bermitra wajib menjual hasil produksi tanaman kepada PT. Silva Inhutani dengan harga pasar

Pada dasarnya kemitraan merupakan sebuah hubungan atau jalinan kerja sama berdasarkan perjanjian yang disepakati untuk mencapai tujuan tertentu (Robert dalam Supratman 2016: 45). Senada dengan hal tersebut, Menurut Sumarto (2009: 116) kemitraan adalah hubungan yang terjadi antara civil society, pemerintah dan atau sektor swasta dalam rangka mencapai suatu tujuan yang didasarkan pada prinsip kepercayaan, kesetaraan, dan kemandirian. Berdasar pada pengertian di atas, kemitraan pengelolaan hutan merupakan pelaksanaan pengelolaan hutan yang dilakukan oleh badan usaha yang merupakan kolaborasi antara Pemerintah, Perusahaan dan Masyarakat dengan segala hak dan kewajiban pengelolaan hutan berdasarkan perjanjian yang disepakati.

Dalam Implementasinya, tidak semua kebijakan bermuara pada sebuah keberhasilan, mengingat implementasi lebih sukar dibandingkan dengan perumusan kebijakan. Hal ini dikarenakan kondisi di lapangan terkadang kerap berubah dan sulit di prediksi. Kondisi yang menunjukan adanya kesenjangan antara tujuan yang diharapkan dengan realitas yang telah dicapai ini disebut sebagai Implementation Gap (Wahab, 1997:61).

Implementasi memiliki persentase $60 \%$ dari keberhasilan sebuah kebijakan. Sedangkan rencana adalah $20 \%$ dan $20 \%$ sisanya adalah bagaimana kita mengendalikan implementasi (Nugroho, 2014: 625).

Demi tercapainya tujuan dari program kemitraan pengelolaan hutan ini, maka perlu adanya peran dan kolaborasi yang baik antara tiga pihak yang bermitra yaitu Pemerintah, Perusahaan dan Masyarakat dalam menjalankan program kemitraan pengelolaan hutan ini. Program kemitraan pengelolaan hutan ini merupakan bagian dari implementasi kebijakan publik. Hal ini didasarkan pada pendapat Thomas $\mathrm{R}$. Dye mendefinisikan bahwa kebijakan publik adalah "whatever government choose to do or not to do" (Winarno, 2009 : 17).

Di lain sisi Tachjan (2006: 33) juga menyatakan bahwa "Program merupakan bentuk dari implementasi kebijakan yang diikuti proyek atau kegiatan sampai dengan manfaat dari kebijakan". Kebijakan administratif yang masih berupa pertanyaan-pertanyaan umum yang berisikan tujuan, sasaran, serta berbagai macam sarana, agar dapat diimplementasikan perlu dijabarkan lagi ke dalam program-program yang bersifat operasional.

Oleh sebab itu Penelitian ini akan melihat bagaimana pelaksanaan kemitraan pengelolaan hutan Register 45 Kabupaten Mesuji yang meliputi identifikasi masyarakat pengguna lahan hutan dan sosialisasi, membangun 


\section{Jurnal Ilmu Pemerintahan: Kajian Ilmu Pemerintahan dan Politik Daerah, 3 (2), Oktober 2018 - 184 \\ Andrialius Feraera1) *, Nandang Alamsah D2), Neneng Yani Yuningsih ${ }^{3)}$}

kesepakatan kemitraan dan pelaksanaan program kemitraan (Adnan, Berliani, Hardiyanto, \& Sakti, 2015). Selanjutnya, dari proses implementasi tersebut maka akan terlihat faktor-faktor yang mempengaruhi implementasi kebijakan kemitraan pengelolaan hutan antara pemerintah Kabupaten Mesuji, perusahaan (PT. Silva Inhutani) dan masyarakat.

Secara teoritik variabel-variabel yang dapat mempengaruhi tercapainya tujuan dari proses implementasi program kemitraan pengelolaan hutan ini menurut Mazmanian dan Sabatier adalah pertama, struktur manajemen kebijakan yang meliputi kejelasan dan konsistensi tujuan yang akan dicapai, dukungan teoritis, sumber dana, dasar hukum yang jelas, keterpaduan hirarki dan perekrutan pejabat pelaksana dan keterbukaan kepada pihak luar. Kedua, faktor-faktor di luar peraturan yang meliputi: kondisi sosial ekonomi dan teknologi, dukungan publik, sikap masyarakat, komitmen dan keahlian pada pelaksana kebijakan (Mazmanian \& Sabatier, 1989).

\section{METODE}

Penelitian ini menggunakan metode kualitatif dengan pendekatan studi kasus. Sebuah eksplorasi dari suatu sistem yang terikat atau suatu kasus/beragam kasus yang dari waktu ke waktu melalui pengumpulan data yang mendalam serta melibatkan berbagai sumber informasi yang kaya dalam suatu konteks (Lewis, 2015).

Penelitian ini dilakukan di Kabupaten Mesuji Provinsi Lampung tepatnya di Kawasan Hutan Register 45.
Teknik pengumpulan data dalam penelitian ini adalah dengan melakukan observasi, wawancara dan dokumentasi. Penetuan informan dilakukan dengan purposive, yaitu dilakukan sesuai dengan kebutuhan penelitian diantaranya Pemerintah Kabupaten Mesuji, Dinas Kehutanan Provinsi Lampung, Perusahaan, Kelompok Tani, Kepolisian, LSM Agra dan Akademisi.

Teknik analisis data yang digunakan adalah dengan tiga alur kegiatan yang terjadi secara bersamaan yaitu reduksi data, penyajian data, penarikan kesimpulan atau verifikasi (Weiss, n.d.). Guna memperoleh data yang valid maka dilakukan triangulasi data dengan mengecek kebenaran informasi di lapangan (Lexy \& Moleong, 2004).

Adapun konsep yang digunakan dalam penelitian ini untuk menjelaskan pelaksanaan kemitraan pengelolaan hutan adalah konsep (Adnan et al., 2015) yang terdiri dari indikator sebagai berikut:

1. Identifikasi masyarakat pengguna lahan hutan dan sosialisasi,

2. Membangun kesepakatan kemitraan

3. Pelaksanaan program kemitraan

Untuk menjelaskan faktor yang menghambat dan mendukung inplementasi kebijakan maka digunakan konsep (Mazmanian \& Sabatier, 1989) yaitu:

1. Struktur manajemen program yang mengoperasionalkan kebijakan.

a. Kejelasan dan Konsistensi Tujuan

Semakin mampu suatu peraturan memberikan petunjukpetunjuk yang cermat dan disusun secara jelas dengan skala prioritas/ 
Jurnal Ilmu Pemerintahan: Kajian Ilmu Pemerintahan dan Politik Daerah, 3 (2),

Oktober 2018 - 185

Andrialius Feraera ${ }^{1)}$ *, Nandang Alamsah ${ }^{2}$ ), Neneng Yani Yuningsih ${ }^{3)}$

urutan kepentingan bagi para pejabat pelaksana dan aktor lainya, maka semakin besar pula kemungkinan keberhasilan implementasi kebijaka.

b. Dukungan Teoritis

Memuat suatu teori kausal yang menjelaskan bagimana kirakira tujuan usaha pembaharuan yang akan dicapai melalui implementasi kebijakan.

c. Sumber Dana

Tersedianya dana pada tingkat batas ambang tertentu sangat diperlukan agar terbuka peluang untuk mencapai tujuantujuan formal.

d. Keterpaduan Hirarki di dalam lingkungan dan diantara lembagalembaga atau instansi-instansi pelaksana.

e. Dasar hukum Yang Jelas.

f. Perekrutan Pejabat Pelaksana.

Para pejabat pelaksana memiliki dan memenuhi kemampuan yang disyaratkan demi tercapainya tujuan.

g. Keterbukaan Kepada Pihak Luar

2. Faktor-faktor di luar peraturan.

a. Kondisi Sosial Ekonomi dan Teknologi.

Kondisi sosial, ekonomi dan teknologi sangat berpengaruh terhadap upaya pencapaian tujuan yang telah ditetapkan.

b. Dukungan publik.

Untuk mendorong tingkat keberhasilan suatu implementasi kebijakan sangat dibutuhkan adanya sentuhan dukungan dari masyarakat.

c. Sikap masyarakat.

Ada semacam karifan lokal yang dimiliki oleh warga yang dapat mempengaruhi keberhasilan atau ketidakberhasilan kebijakan.

d. Komitmen dan keahlian pada pelaksana kebijakan.

Kemampuan berinteraksi antar lembaga atau individu di dalam lembaga untuk mensukseskan implementasi kebijakan menjadi indikasi penting keberhasilan kinerja kebijakan publik. (Mazmanian \& Sabatier, 1989)

\section{HASIL PENELITIAN}

\section{A. Impelementasi Kebijakan Ke- mitraan Pengelolaan Hutan di Register 45 \\ Identifikasi dan Sosialisasi Kemitraan \\ Masyarakat perambah di kawasan Hutan Register 45 dapat diidentifikasi sebagai berikut:}

Tabel1. Data identifikasi Perambah Hutan Register 45.

\begin{tabular}{|c|c|c|c|}
\hline \multirow[t]{2}{*}{ No } & \multirow[t]{2}{*}{ Data Lokasi Perambah } & \multicolumn{2}{|c|}{ Jumlah Perambah } \\
\hline & & KK & $\begin{array}{l}\text { Pondok } \\
\text { /Rumah }\end{array}$ \\
\hline 1 & $\begin{array}{l}\text { Divisi } 4 \text { A Blok } 26 \text { PT. Silva } \\
\text { (Eks. Kampung Karya } \\
\text { Jaya) }\end{array}$ & 2.470 & 2.310 \\
\hline 2 & $\begin{array}{l}\text { Divisi 4A Blok } 16 \text { PT. Silva } \\
\text { (Karya Tani) }\end{array}$ & 850 & 850 \\
\hline 3 & $\begin{array}{l}\text { Divisi IA Blok } 10 \text { (Eks. } \\
\text { Pelita Jaya) }\end{array}$ & 600 & 621 \\
\hline 4 & $\begin{array}{l}\text { Divisi 1A Blok } 4 \text { Kamp. } \\
\text { Air Mati) }\end{array}$ & 735 & 621 \\
\hline 5 & $\begin{array}{l}\text { Divisi 8A Blok } 10 \text { dan } 11 \\
\text { (Eks. Kamp. SukaAgung) }\end{array}$ & 450 & 655 \\
\hline 6 & Alba 2 Blok Sawit 99 & 675 & 831 \\
\hline 7 & $\begin{array}{l}\text { Depan SMK Patriot } \\
\text { Simpang Pematang }\end{array}$ & 525 & 400 \\
\hline
\end{tabular}


Jurnal Ilmu Pemerintahan: Kajian Ilmu Pemerintahan dan Politik Daerah, 3 (2),

Oktober 2018 - 186

Andrialius Feraera1) *, Nandang Alamsah D²), Neneng Yani Yuningsih ${ }^{3)}$

\begin{tabular}{|c|c|c|c|}
\hline 8 & $\begin{array}{l}\text { Divisi 8A Blok } 8 \text { Dan } 9 \\
\text { Tugu Roda }\end{array}$ & 716 & 716 \\
\hline 9 & $\begin{array}{l}\text { Divisi } 10 \text { A Blok } 19 \text { (Kp. } \\
\text { Marga Jaya) }\end{array}$ & 413 & 415 \\
\hline 10 & $\begin{array}{l}\text { Divisi } 10 \text { A Blok } 27 \text { Kp. } \\
\text { (Tunggal Jaya) }\end{array}$ & 500 & 726 \\
\hline 11 & $\begin{array}{l}\text { Divisi 6A Blok } 21 \text { dan 5B } \\
\text { (Pok Mesuji Raya) }\end{array}$ & 715 & 743 \\
\hline 12 & $\begin{array}{l}\text { Divisi } 10 \text { A Blok } 29 \\
\text { Simpang D }\end{array}$ & 135 & 140 \\
\hline & TOTAL & $\begin{array}{c}8.784 \\
\text { KK } \\
(17.569 \\
\text { Jiwa) }\end{array}$ & $\begin{array}{l}9.068 \\
\text { (Unit) }\end{array}$ \\
\hline
\end{tabular}

Sumber: Laporan Hasil Kegiatan Operasi Gabungan Penertiban KHP Reg. 452013

Sosialisasi rencana kemitraan dilakukan pertama kali pada tahun 2014 di luar Kabupaten Mesuji diikuti oleh perwakilan masyarakat (Karya-Karya). Sampai pada akhir tahun 2014 baru kelompok Sido Rukun yang sepakat untuk bermitra. Skema kemitraan yang ditawarkan oleh Kementerian Kehutanan adalah PT. Silva Inhutani sebagai Pemegang Izin Usaha (IUPHH) dalam hal ini pihak pertama mengajak masyarakat perambah pihak kedua untuk melakukan kerja sama mengenai penanaman kembali Hutan Tanaman Industri Register 45.

Gambar 1. Skema Kemitraan yang Di Tawarkan

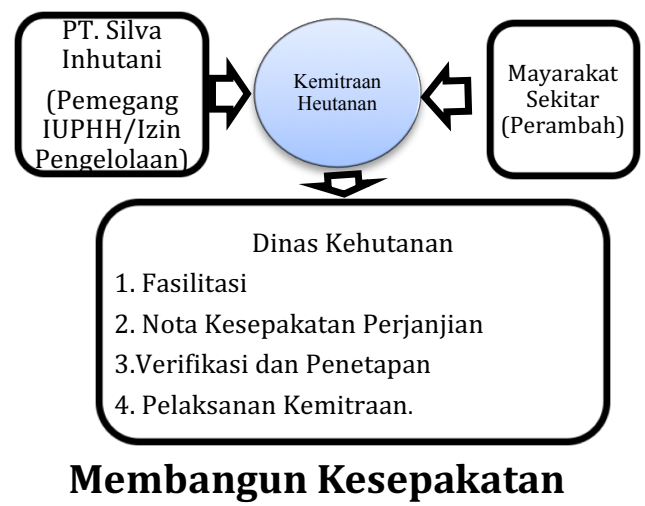

Pada Bulan September 2015 akhirnya terjalin kemitraan dengan ditandatanganinya perjanjian kerja sama Kemitraan HTI Register 45 antara PT. Silva Inhutani selaku pihak pertama dengan Masyarakat Perambah selaku pihak ke kedua yaitu Kelompok Marga Jaya, Sido Rukun, Karya Jaya, Karya Tani, Maju Jaya dan Mekar Jaya Abadi dengan jangka waktu 6 (enam) terhitung setelah realisasi tanaman akasia pada tahun 2016 (Pasal 6 Perjanjian Kemitraan).

Pemerintah mengalokasikan $20 \%$ atau 8620 Ha dari 43.100 Ha dan setiap keluarga akan mendapatkan maksimal 2 Ha. Adapun kesepakatan yang terbangun diaur dalam Pasal 3 perjanjian kemitraan yaitu:

1. Tanaman kemitraan kehutanan berupa tanaman pokok kayu dan tanaman semusim sesuai dengan peraturan perundang-undangan tentang penataan ruang dan rencana kerja pihak pertama.

2. Tanaman pokok kayu adalah berupa tanaman akasia dan/atau tanaman berkayu lainnya sesuai dengan rencana pihak usaha pihak kedua.

3. Tanaman semusim adalah berupa tanaman singkong dan/atau tanaman lainnya sesuai dengan rencana usaha/RKU Pihak Pertama.

4. Pembagian Hasil budidaya kemitraan didasarkan atas pendapatan bersih panen tanaman kemitraan setelah dikurangi seluruh biaya permodalan budidaya dan kewajiban terhadap negara dengan proposisi.

- Untuk tanaman pokok kayu Akasia Mangunium bagi hasil 
Jurnal Ilmu Pemerintahan: Kajian Ilmu Pemerintahan dan Politik Daerah, 3 (2),

Oktober $2018-187$

Andrialius Feraera1) *, Nandang Alamsah ${ }^{2)}$, Neneng Yani Yuningsih ${ }^{3)}$

yang disepakati adalah 75\% untuk perusahaan dan 25\% untuk masyarakat dengan ketentuan hasil produksi setelah dipotong modal yang dikeluarkan oleh perusahaan.

- Untuk tanaman semusim yakni singkong, bagi hasil yang disepakati adalah 50\% untuk perusahan dan $50 \%$ untuk masyarakat dengan ketentuan hasil produksi singkong dipotong modal produksi.

5. Pihak kedua akan melaksanakan penanaman tanaman pokok kayu seluas $20 \%$ dari lahan yang digarap dan selanjutnya setiap tahun ditambah 20\% dari sisa lahan yang di garap (Pasal 3 Perjanjian Kemitraan)

Perjanjian kerja sama kemitraan pengelolaan hutan juga memuat tugas dan Kewajiban Pihak Pertama (PT. Silva Inhutani) dan Pihak Kedua (Masyarakat Perambah). Adapun kewajiban pihak pertama adalah:

1. Bersama pihak kedua mengatur, menentukan kelompok masyarakat yang dilibatkan dalam perjanjian ini dalam bentuk organisasi kemitraan yang dilegalkan menjadi badan hukum dalam bentuk koperasi.

2. Mengatur dan menentukan lahan yang dipersiapkan untuk ditanami tanaman pokok kayu dan tanaman semusim lainnya yang dipandang baik oleh pihak pertama dengan melibatkan pihak kedua bersama koperasi.
3. Menentukan dan memberikan bimbingan teknis peserta kemitraan untuk mengikuti aturan yang telah disepakati kedua belah pihak.

4. Membeli semua hasil produksi tanaman pokok kayu dan tanaman semusim lainnya dengan harga pasar yang berlaku fleksibel.

5. Menyediakan modal untuk budidaya tanaman kemitraan

6. Bertanggung jawab atas pelaksanaan kegiatan teknis budidaya tanaman kemitraan sebagaimana dimaksud pada pasal 3 ayat 1 sesuai dengan yang telah disepakati bersama oleh pihak pertama dan kedua (Pasal 4 Perjanjian Kemitraan)

Tugas dan Kewajiban Pihak Kedua (Kelompok Tani)

1. Pihak pertama membentuk organisasi dengan badan hukum berbentuk koperasi.

2. Koperasi sebagaimana dimaksud dalam poin satu diatas melaksanakan kegiatan budidaya tanaman Kemitraan Kehutanan berupa tanaman kayu dan tanaman semusim lainnya dengan sistem pengelolaan bersama, sesuai dengan struktur organisasi Kemitraan yang membuat pengurus TPK, Pengurus kelompok dan anggota.

3. Menjual hasil produksi tanaman kayu dan tanaman semusim kepada pihak pertama dengan harga pasar yang fleksibel

\section{Pelaksanaan Kemitraan}


Jurnal Ilmu Pemerintahan: Kajian Ilmu Pemerintahan dan Politik Daerah, 3 (2),

Oktober 2018 - 188

Andrialius Feraera ${ }^{1)}$ *, Nandang Alamsah ${ }^{2}$ ), Neneng Yani Yuningsih ${ }^{3)}$

Rencana realisasi kemitraan dimulai dengan menanami 20\% dari setiap garapan masyarakat. Teknisnya adalah pada tahun pertama yaitu tahun 2016 akan ditanami 20\% tanaman akasia atau 1133,3 Ha dari lahan yang dimitrakan dan $80 \%$ akan ditanami tanaman semusim. Setiap tahun akan bertambah 20\% hingga masa kontrak 6 tahun. Sehingga diharapkan di tahun ke 6 masyarakat yang bermitra sudah menanam tanaman akasia $100 \%$.

Namun dalam kenyataannya, per Desember 2017 realisasi penanaman akasia hanya pada penanaman percontohan di pekarangan, penanaman akasia 12 Ha pada Kelompok Marga Jaya dan penanaman akasia $33 \mathrm{Ha}$ di kelompok Sido Rukun.

Tabel 2. Realisasi Kemitraan

\begin{tabular}{|c|c|c|}
\hline Kelompok & $\begin{array}{c}\text { Realisasi } \\
\text { (Ha) }\end{array}$ & $\begin{array}{r}\text { irget Tahun } \\
2016(\mathrm{Ha})\end{array}$ \\
\hline Marga Jaya & 12 & 68,4 \\
\hline Tugu Roda & - & 50 \\
\hline Sido Rukun & 44 & 67 \\
\hline Karya Jaya & 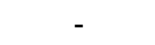 & 438 \\
\hline Karya Tani & - & 220 \\
\hline Maju Jaya & - & 136 \\
\hline Mekar Jaya & - & 153,9 \\
\hline
\end{tabular}

Sumber: Diolah oleh peneliti tahun 2018

Realisasi kemitraan ini sangat jauh dari target yang ditetapkan sebesar 20\% dari jumlah garapan di 7 (Tujuh) Kelompok yang bermitra. Realisasinya hanya sebesar $45 \mathrm{Ha}$ atau 3,97\% dari target tahun pertama di tujuh kelompok adalah 1133,3 Ha. Untuk tanaman semusim berupa singkong, dalam kenyataannya tidak dimitrakan artinya masyarakat yang mengeluarkan modal sendiri dan tidak sesuai dengan perjanjian yang telah ditandatangani (Wahab, n.d.).

Kemitraan yang tidak berjalan dengan baik ini juga diakui oleh Dinas Kehutanan dan Pemerintah Kabupaten Mesuji yang tertuang dalam Laporan Perkembangan di Wilayah Register 45 Kabupaten Mesuji Provinsi Lampung yang ditujukan kepada Menteri Dalam Negeri No 3 Tahun 2016 yang menyebutkan bahwa penanganan konflik sosial di Register 45 hingga saat ini masih belum bisa ditangani. Lebih lanjut, saat ini pola kemitraan tidak berjalan karena banyak perambah yang tidak menyetujuinya

\section{B. Faktor Pengaruh Kebijakan Kemitraan Pengelolaan Hutan Register 45.}

\section{Dimensi Struktur Manajemen Kebijakan}

\section{Kejelasan dan Konsistensi tujuan yang Akan Dicapai.}

Secara khusus tujuan dari kemitraan pengelolaan hutan register 45 ini adalah pertama, menghentikan konflik yang terjadi antara perusahaan dan masyarakat perambah yang masuk ke KHP Register 45 maupun konflik antar masyarakat perambah. Kedua, menghentikan perambahan dan monopoli kepemilikan lahan. Ketiga, mengembalikan kawasan Register 45 menjadi Kawasan Hutan Industri. Sampai saat ini capaian tujuan dari kemitraan pengelolaan hutan ini adalah hanya dapat meredam konflik. Sementara itu monopoli kepemilikan lahan masih saja terjadi. 
Jurnal Ilmu Pemerintahan: Kajian Ilmu Pemerintahan dan Politik Daerah, 3 (2),

Oktober 2018 - 189

Andrialius Feraera1) *, Nandang Alamsah ${ }^{2)}$, Neneng Yani Yuningsih ${ }^{3)}$

Poin kesepakatan yang berjalan selanjutnya hanyalah penanaman akasia dan penanaman singkong tidak dimitrakan. Sementara itu dalam MOU kemitraan Pasal 3 disebutkan bahwa tanaman semusim berupa singkong adalah tanaman yang dimitrakan dengan modal budidaya ditanggung oleh PT. Silva Inhutani. Dalam kenyataannya masyarakat melakukan penanaman singkong dengan modal sendiri (KJ Ferdian, 2017).

\section{Dukungan Teoritis}

Adanya pemberdayaan masyarakat dalam mengelola hutan di daerah lain yang berhasil menjadi salah satu faktor yang mendukung kepada pemerintah untuk menerapkan program kemitraan pengelolaan hutan di Register 45 ini. Hal ini terbukti dari adanya kemitraan pengelolaan hutan jati di Jawa Tengah tepatnya di KHP Kendal, KHP Semarang dan KHP Purwodadi tahun 2005 (Hakim, 2009). Saat itu disebut sebagai Pengelolaan Hutan Bersama Masyarakat (PHBM). PHBM ini berdasar pada Peraturan Pemerintah No 30 Tahun 2003 tentang Perusahaan Umum Kehutanan Negara.

\section{Sumber Dana}

Pasal 18 ayat 2 Permenhut P.39/Menhut-II/2013 menyebutkan bahwa biaya pelaksanaan kegiatan Kemitraan Kehutanan sesuai dengan Naskah Kemitraan Kehutanan menjadi tanggung jawab Pengelola Hutan, Pemegang Izin, KPH dan swadaya masyarakat setempat. Kesepakatan ini juga tertuang dalam MOU Kemitraan Pasal 4 di mana pihak pertama PT. Silva Inhutani berkewajiban menyediakan modal untuk budidaya kemitraan.

\section{Dasar hukum Yang Jelas}

Dalam hal kemitraan pengelolaan hutan, yang menjadi dasar hukum adalah pertama Undang-Undang Nomor 41 Tahun 1999 Tentang Kehutanan Pasal 68 ayat (1) UU 41 Tahun 1999 Pasal 69 ayat (1). Pengelolaan hutan melalui kemitraan secara spesifik diatur dalam Peraturan Menteri Kehutanan No. P.39/ Menhut-II tentang Pemberdayaan Masyarakat melalui Kemitraan Kehutanan. Kesepakatan antara pemegang ijin usaha hutan dengan masyarakat kemudian dituangkan dalam naskah Kemitraan Kehutanan. Akan tetapi, terdapat kelemahan yang menjadi penghambat kemitraan adalah tidak adanya sangsi yang tertuang dalam naskah perjanjian sehingga membuat kedua belah pihak bebas melakukan pelanggaran.

Tabel 5. Pelanggaran Pihak Pertama dan Kedua dalam Kemitraan Pengelolaan Hutan Register 45.

\begin{tabular}{|c|c|c|}
\hline No & $\begin{array}{c}\text { Pelanggaran } \\
\text { Oleh } \\
\text { Masyarakat }\end{array}$ & $\begin{array}{c}\text { Pelanggaran } \\
\text { oleh PT. Silva } \\
\text { Inhutani }\end{array}$ \\
\hline 1 & $\begin{array}{l}\text { Masih terjadi } \\
\text { monopoli } \\
\text { kepemilikan }\end{array}$ & $\begin{array}{lr}\text { PT. Silva } \\
\text { Inhutani tidak } \\
\text { memberikan }\end{array}$ \\
\hline & $\begin{array}{l}\text { lahan oleh } \\
\text { anggota mitra. } \\
\text { Terdapat } \\
\text { masyarakat } \\
\text { yang menanami } \\
\text { singkong lebih } \\
\text { dari 2 Ha. }\end{array}$ & $\begin{array}{lr}\text { bibit } & \text { akasia } \\
\text { impor } & \text { seperti } \\
\text { yang dijanjikan }\end{array}$ \\
\hline 2 & $\begin{array}{l}\text { Masyarakat } \\
\text { masih menanam } \\
100 \% \text { lahan } \\
\text { dengan } \\
\text { singkong. }\end{array}$ & $\begin{array}{l}\text { Perusahaan } \\
\text { tidak } \\
\text { membiayai } \\
\text { tanaman } \\
\text { semusim. }\end{array}$ \\
\hline
\end{tabular}


Jurnal Ilmu Pemerintahan: Kajian Ilmu Pemerintahan dan Politik Daerah, 3 (2),

Oktober 2018 - 190

Andrialius Feraera ${ }^{1)}$ *, Nandang Alamsah ${ }^{2}$ ), Neneng Yani Yuningsih ${ }^{3)}$

\begin{tabular}{cll}
\hline \hline 3 & $\begin{array}{l}\text { Terdapat jual } \\
\text { beli lahan mitra }\end{array}$ & $\begin{array}{l}\text { Perusahaan } \\
\text { lebih fokus pada } \\
\text { singkong } \\
\text { dengan } \\
\text { membangun }\end{array}$ \\
& & $\begin{array}{l}\text { lapak-lapak. } \\
\end{array}$ \\
4 & $\begin{array}{l}\text { Terdapat } \\
\text { oknum-oknum } \\
\text { yang merusak } \\
\text { tanaman akasia. }\end{array}$ \\
\hline \hline
\end{tabular}

Sumber: Diolah dari data lapangan

\section{Perekrutan Pejabat Pelaksana dan Keterpaduan Diantara Lembaga Pelaksana.}

Keterpaduan antara lembagalembaga lain dalam membantu Dinas Kehutanan inilah yang akhirnya membuat kemitraan pengelolaan hutan antara PT. Silva Inhutani dan Masyarakat Perambah Terjalin. Pasca terjalin kemitraan kemudian keterpaduan ini tidak tampak lagi mengingat tidak adanya pendampingan pasca terjalin kemitraan terlebih dengan ditariknya Dinas Kehutanan Kabupaten ke Provinsi pada tahun 2017.

\section{Keterbukaan Kepada Pihak Luar}

Berdasar penelitian dapat dilihat bahwa meskipun Kemitraan ini tidak berjalan seperti yang diharapkan tetapi Dinas Kehutanan dan Pemerintah Daerah telah mencoba menciptakan situasi yang terbuka kepada masyarakat dengan selalu mencoba melakukan negosiasi. Kondisi sebaliknya dimana PT. Silva dan Masyarakat Perambah yang sangat tertutup kepada pihak luar. Hal ini tentunya dikarenakan adanya perubahan paradigma baru yang coba ditawarkan kepada masyarakat. masyarakat masih belum percaya kepada pemerintah mengingat selama ini pemerintah mencoba untuk menertibkan masyarakat dengan penggusuran.

\section{Dimensi Di Luar Peraturan}

\section{Kondisi Sosial Ekonomi dan Teknologi}

Areal yang dikuasai oleh perambah semakin tahun semakin bertambah yaitu seluas 29.931 Ha dari 25 kelompok 11.025 KK dengan 29.008 Jiwa dan 10.725 gubuk. Sementara itu area yang dikelola PT. Silva Inhutani hanya seluas 13.169 yang terdiri dari 11.684 ha perkebunan dan $1.485 \mathrm{Ha}$ adalah fasilitas umum. Modus yang dilakukan oleh masyarakat dalam melakukan perambahan mulai dari klaim masyarakat adat, pencurian kayu, jual beli lahan kawasan hingga pembuatan pemukiman yang sistematis dan mengarah permanen.

Kondisi lainnya yang sering terjadi di Kawasan Hutan Register 45 yaitu rentan terjadi konflik antara warga pendatang dengan penduduk asli. Wilayah Register 45 pernah menduduki rangking pertama di Indonesia dalam sengketa tanah di tahun 2011-2013 versi BPN Pusat. Selanjutnya kawasan Register 45 juga masuk dalam kategori GUAN KTMS Kadar Tinggi dengan Senjata Api Organik atau Rakitan selama 3 tahun terakhir (Data Karo Ops Polda Lampung). Hal ini dapat dilihat dari aktivitas para perambah dan pengawal kepala blok yang turut dipersenjatai dengan senjata api.

Masalah dominan lainnya yang terjadi di kawasan hutan Register 45 adalah Premanisme. Masyarakat pe- 


\section{Jurnal Ilmu Pemerintahan: Kajian Ilmu Pemerintahan dan Politik Daerah, 3 (2), \\ Oktober 2018 - 191 \\ Andrialius Feraera ${ }^{1)}$ *, Nandang Alamsah ${ }^{2}$ ), Neneng Yani Yuningsih ${ }^{3)}$}

rambah selalu merasakan adanya pemalakan oleh kelompok preman (kepala blok) ketika melakukan pemanenan singkong. Sebelumnya, jika masyarakat ingin menggarap salah satu lahan di Kawasan Register 45 maka mereka harus membayar kepada kepala blok sebagai uang keamanan. Premanisme yang terjadi di Kawasan Register 45 ini akhirnya ikut menyumbang sebagai faktor penghambat keberhasilan kemitraan pengelolaan hutan ini. Aksi premanisme dengan melakukan intimidasi kepada warga yang ikut kemitraan akhirnya menimbulkan rasa takut pada masyarakat yang ikut bermitra.

\section{Dukungan Publik}

Lembaga Swadaya Masyarakat yang saat ini berfokus pada pendampingan masyarakat Register 45 diantaranya adalah Persatuan Petani Masyarakat Moro-Moro Way Serdang (PPMWS). Selain PPMWS terdapat LSM lain yaitu Aliansi Gerakan Reforma Agraria (AGRA). LSM tersebut adalah LMS yang mendukung masyarakat untuk menolak pola kemitraan yang di tawarkan. Pola kemitraan yang ditawarkan kepada masyarakat dianggap belum dapat menampung aspirasi dari masyarakat sehingga mereka memilih untuk tidak ikut dalam kemitraan tersebut. Salah satu aspirasinya adalah mendapatkan hak-hak konstitusional masyarakat Register 45 yang selama ini tidak pernah diberikan Pemerintah Daerah Kabupaten Mesuji (Wahab, n.d.).

Sementara itu, untuk masyarakat yang saat ini ikut dalam kemitraan yaitu 7 (tujuh) Kelompok tani Karya Tani,
Karya Jaya, Maju Jaya, Marga Jaya, Mekar Jaya, Tugu Roda, Sido Rukun di dampingi oleh LSM Advokasi Rakyat Untuk Nusantara (ARUN). ARUN inilah yang memfasilitasi para anggota kelompok untuk melakukan study banding ke luar Kabupaten Mesuji.

\section{Sikap Masyarakat}

Berdasarkan data yang diperoleh terdapat $2.518 \mathrm{KK}$ yang terbagi dalam tujuh kelompok telah setuju dengan program kemitraan pengelolaan hutan Register 45 yang digagas oleh Kementerian Kehutanan melalui Dinas Kehutanan. Kelompok tersebut adalah Marga Jaya, Tugu Roda, Sido Rukun, Karya Jaya, Karya Tani, Maju Jaya dan Mekar Jaya. Kelompok-kelompok ini secara langsung atau tidak telah setuju dengan program yang ditawarkan berupa pengelolaan hutan bersama melalui kemitraan kehutanan. Mereka yang telah ikut kemitraan sesecara sah telah mengakui bahwa lahan yang mereka tinggali dan tanami adalah lahan miliki negara yaitu Kementerian Kehutanan. Akan tetapi, jika masyarakat harus ditertibkan dengan cara pindah ke luar Register 45 maka mereka menolak dan siap mempertahankan dengan cara apapun.

\section{Komitmen Pelaksana Kemitraan}

Kemitraan pengelolaan hutan Register 45 ini sangat membutuhkan komitmen dari semua pihak yaitu Dinas Kehutanan sebagai penanggung jawab pelaksanaan kemitraan, PT. Silva Inhutani selaku pihak pertama dalam kemitraan juga masyarakat perambah sebagai pihak kedua yang bermitra dengan PT. Silva Inhutani. Jika dilihat 


\section{Jurnal Ilmu Pemerintahan: Kajian Ilmu Pemerintahan dan Politik Daerah, 3 (2), \\ Oktober 2018 - 192 \\ Andrialius Feraera1) *, Nandang Alamsah ${ }^{2}$ ), Neneng Yani Yuningsih ${ }^{3)}$}

dari proses sosialisasi hingga verifikasi terlihat bahwa ada kesungguhan yang ingin ditunjukan oleh Dinas Kehutanan untuk mengajak masyarakat perambah bermitra dalam mengelola Hutan Register 45. Hal ini terlihat dari upaya yang dilakukan dengan tidak mengenal lelah dari Dinas Kehutanan dalam melakukan sosialisasi meskipun menemui berbagai rintangan. Selanjutnya, jika dilihat lebih dalam masyarakat perambah Register 45 sebenarnya tidak memenuhi syarat sebagai masyarakat mitra hal ini dapat dilihat dari status mereka yang ilegal dan tidak memiliki kartu tanda penduduk (KTP).

Komitmen ini kemudian dirasakan hilang ketika masyarakat yang telah bermitra merasa bahwa program kemitraan pengelolaan hutan ini berjalan seolah tanpa peran dan pendampingan dari Pemerintah. Hal ini dikarenakan adanya peralihan kewenangan Dinas Kehutanan dan Perkebunan ke Pemerintah Provinsi Lampung pada tahun 2017 seiring dengan berlakunya Peraturan Pemerintah Nomor 18 Tahun 2016 tentang Perangkat Daerah. Bidang Kehutanan yang berada pada Dinas Kehutanan dan Perkebunan Kabupaten Mesuji beralih menjadi kewenangan Pemerintah Provinsi Lampung, sedangkan bidang Perkebunan bergabung dengan Dinas Pertanian Kabupaten Mesuji sebagaimana tertuang dalam Peraturan daerah No. 5 Tahun 2016 tentang Pembentukan dan Susunan Perangkat Daerah Kabupaten Mesuji.

Sementara itu PT. Silva Inhutani sebagai pihak pertama sekaligus pemegang
HGU tidak memberikan contoh yang kepada masyarakat dengan fokus pada penanaman pohon akasia. PT Silva Inhutani saat ini terlihat fokus pada tanamantanaman di luar HGU nya seperti pohon karet dan singkong. Di sisi lain masyarakatpun ikut serta dalam kegagalan program kemitraan ini. Program kemitraan yang aturannya menanam $80 \%$ tanaman singkong dan $20 \%$ tanaman akasia dalam kenyataannya tidak direalisasikan dengan baik. Banyak masyarakat yang menanam 100\% lahan garapannya dengan singkong sehingga berdampak pada tanaman akasia yang tidak dapat tumbuh.

\section{PEMBAHASAN}

Berdasarkan pada hasil penelitian maka dapat dilihat faktor penghambat dan pendukung kebijkan kemitraan pengelolaan hutan Register 45. Meskipun Hutan Register 45 telah mengalami kerusakan hebat dan luasan lahan mayoritas dikuasai oleh perambah sehingga mengakibatkan produksi menurun namun berdasar penelitian, ketersediaan dana bukanlah menjadi salah satu faktor penghambat pelaksanaan kemitraan ini. PT. Silva Inhutani merupakan anak perusahan dari PT. Sungai Budi Group yang merupakan salah satu perusahaan terbesar dan tertua di Provinsi Lampung (http://forum.viva.co.id/indeks/threads /profil-pt-silva-inhutani./).

Lebih lanjut, Kabupaten Mesuji hanya memiliki luas wilayah sebesar $2.184 \mathrm{~km}^{2}$ dan jika di konversi kedalam Ha adalah 218.400 Ha. Di wilayah Kabupaten Mesuji, terdapat beberapa anak perusahaan dari PT. Sungai Budi Group yang bergerak di bidang 


\section{Jurnal Ilmu Pemerintahan: Kajian Ilmu Pemerintahan dan Politik Daerah, 3 (2), \\ Oktober 2018 - 193 \\ Andrialius Feraera ${ }^{1)}$ *, Nandang Alamsah ${ }^{2}$ ), Neneng Yani Yuningsih ${ }^{3)}$}

pertanian. PT. Silva Inhutani merupakan salah satu anak perusahaan yang memiliki HGU paling luas sebesar 43. 100 Ha. Artinya PT. Silva Inhutani menguasai 20\% Kabupaten Mesuji. Selain PT. Silva Inhutani, juga terdapat beberapa anak perusahaan yang bergerak di wilayah Kabupaten Mesuji. Artinya, hampir sebagian wilayah Kabupaten Mesuji dan kawasan industri dikuasai oleh PT. Sungai Budi Group

Selanjuntnya, Adanya Pengelolaan Hutan Bersama (PHBM) di daerah lain yang berhasil membuat pemerintah merasa percaya diri untuk menerapkan program kemitraan ini di Kawasan register 45. Hal ini menunjukan bahwa program pengelolaan hutan melalui kemitraan ini merupakan program lama yang kemudian di perbaharui dengan nama yang baru. Pemerintah mencoba mengadopsi pola pemberdayaan masyarakat dalam pengelolaan hutan di Register 45.

Disisi lain, faktor penghambat implementasi kebijakan kemitraan pengelolaan lebih dominan dibandingkan pendukungnya. Pertama kurangnnya konsistensi dalam pencapaian tujuan Kemitraan Pengelolaan Hutan Register 45. Dalam pelaksanaannya, masyarakat masih dapat menggarap lebih dari 2 Ha. Hal ini tentu bertentangan dengan Permenhut No P.39/Menhut-II/2013 yang menyebutkan bahwa lahan garapan masyarakat maksimal $2 \mathrm{Ha}$.

Lebih lanjut, pembentukan kesepakatan yang dilakukan oleh Dinas Kehutanan tidak sesuai dengan tahaptahap yang harus dilalui sehingga menyulitkan dalam realisasi kemitraannya. Tahapan yang dilakukan adalah sosialisasi, penandatanganan MOU, indentifikasi dan sosialisasi kembali. Sedangkan tahapan yang seharusnya adalah sosialisasi dan identifikasi, membangun kesepakatan dan pelaksanaan (Adnan et al., 2015). Pasca penandatanganan MOU maka tahap selanjutnya yang harus dilakukan adalah realisasi penanaman pohon alkasia dan bukan melakukan sosialisasi dan verifikasi kelompok.

Tabel 3. Progres Kemitraan Pasca Penandatanganan MOU

\begin{tabular}{|c|c|}
\hline Tanggal & Kegiatan \\
\hline $30-09-2015$ & Penandatanganan MOU \\
\hline & $\begin{array}{l}\text { Kemitraan pada } 7 \text { (tujuh) } \\
\text { kelompok. }\end{array}$ \\
\hline $16-11-2015$ & Verifikasi di Marga Jaya \\
\hline 24-11-2015 & $\begin{array}{l}\text { Verifikasi di Karya Tani, } \\
\text { Karya Jaya, Maju Jaya, Marga } \\
\text { Jaya Sido Rukun dan Tugu } \\
\text { Roda. }\end{array}$ \\
\hline $3 \&-12-2015$ & $\begin{array}{l}\text { Pembahasan Hasil Verifikasi } \\
\text { Kelompok Tani Mitra }\end{array}$ \\
\hline 11-14 Januari & Verifikasi kemitraan di Sido \\
\hline 2016 & Rukun \\
\hline $22 \& \quad 25$ & Verifikasi Kemitraan Karya \\
\hline Januari 2016 & Jaya \\
\hline 27-29 Januari & Verifikasi Kemitraan Karya \\
\hline 2016 & Jaya dan Marga Jaya \\
\hline $24 \quad$ Februari & Rapat tindak \\
\hline 2016 & kemitraan dan cek lapangan. \\
\hline 10-14 Maret & Verifikasi kelompok Mekar \\
\hline 2016 & Jaya Abadi \\
\hline Maret & Sosialisasi \\
\hline 2016 & kembali di Tugu Roda \\
\hline 8 Maret 2016 & $\begin{array}{l}\text { Mediasi dan dialog bersama } \\
\text { masalah di Tugu Roda }\end{array}$ \\
\hline
\end{tabular}




\section{Jurnal Ilmu Pemerintahan: Kajian Ilmu Pemerintahan dan Politik Daerah, 3 (2), Oktober 2018 - 194 \\ Andrialius Feraera1) *, Nandang Alamsah D²), Neneng Yani Yuningsih ${ }^{3)}$}

Sumber: Diolah dari buku saku informasi KHP Register 45

Pada dasarnya, kemitraan ini timbul karena adanya keinginan untuk mengadakan hubungan konsensual, di mana keinginan itu timbul bukan karena diatur oleh undang-undang melainkan dari masing-masing pribadi para pihak (Ansell \& Gash, 2007). Semua masukan, proses dan keluaran Kemitraan Kehutanan dibangun berdasarkan kesepakatan antara para pihak dan bersifat mengikat. Dengan sifatnya yang mengikat maka perlu adanya sangsi yang tegas (dasar hukum) jika ada salah satu pihak yang melakukan pelanggaran sehingga kedua belah pihak memahami tugas dan kewajiban masing-masing. Sangsi yang tegas ini belum masuk dalam naskah perjanjian sehingga pihak yang bermitra bebas melakukan pelanggaran.

Ketiga, Tidak adanya peran pemerintah pasca terjalin kemitraan membuat masyarakat tidak tau harus mengadukan ke mana mengenai masalah-masalah yang timbul dalam pelaksanaan kemitraan. Pasalnya dalam kemitraan pengelolaan hutan di KHP Register 45 ini sangatlah minim akan pendampingan dari pihak luar yaitu LSM, Media dan perguruan Tinggi. Di sisi lain Pemerintah Kabupaten Mesuji juga seperti lepas tangan akan keberlangsungan dari kemitraan pengelolaan hutan ini karena merasa bahwa pasca konflik berakhir maka tanggung jawab kemitraan sepenuhnya berada pada Dinas Kehutanan. Hal ini menunjukan kurangnya keterpaduan dari pelaksana kebijakan.

Keempat, perubahan paradigma baru yang coba ditawarkan Pemerintah kepada masyarakat ini belum sepenuhnya di diterima dan belum bisa membuat masyarakat lebih terbuka. Masyarakat masih belum percaya kepada pemerintah mengingat selama ini pemerintah mencoba untuk menertibkan masyarakat dengan cara penggusuran.

Sementara itu, faktor yang paling dominan dalam menghambat pelaksanaan kebijakan kemitraan ini adalah faktor diluar peraturan yaitu kondisi sosial khususnya keamanan di Register 45. Angka kriminalitas yang tinggi dan besarnya pengaruh kepala blok membuat pemerintah kesulitan menerapkan kebijakan kemitraan ini. Disisi lain, Peneliti melihat kondisi keamanan di Register 45 merupakan situasi yang sengaja diciptakan tetapi ada pula yang memang murni terjadi. Premanisme dan kejahatan yang terjadi sengaja dilakukan untuk menciptakan suasana tidak kondusif yang akhirnya membuat masyarakat merasa tidak nyaman untuk tinggal di kawasan Hutan Register 45. Hal ini bisa dilihat dari lemahnya penegakan hukum di wilayah Register 45. Padahal, Pemerintah Daerah dan Kepolisian memiliki data yang lengkap mengenai siapa yang menguasai dan siapa yang melakukan pemerasan kepada masyarakat.

Rendahnya dukungan publik dapat dilihat dari minimnya pendampingan dari Lembaga Swadaya Masyarakat dan Perguruan tinggi dalam hal kemitraan pengelolaan hutan ini akhirnya membuat kemitraan pengelolaan ini seolah tanpa stakeholder pendukung. Selanjutnya, minimnya dukungan masyarakat 


\section{Jurnal Ilmu Pemerintahan: Kajian Ilmu Pemerintahan dan Politik Daerah, 3 (2), Oktober 2018 - 195 \\ Andrialius Feraera1) *, Nandang Alamsah D²), Neneng Yani Yuningsih ${ }^{3)}$}

juga dapat dilhat dari jumlah kepala keluarga (KK) yang setuju dengan kebijakan kemitraan pengelolaan hutan. Jumla KK yang setuju hanya $2.518 \mathrm{KK}$. Jumlah tersebut adalah 26\% dari jumlah KK masyarakat perambah di Register 45 diluar kelompok Moro-Moro dan Talang Gunung. Masyarakat yang tidak setuju dengan kemitraan memiliki banyak alasan diantaranya adanya lahan yang dimitrakan terlalu sedikit, keinginan menanam karet, bagi hasil yang tidak sesuai, masyrakat tetap tidak mendapat hak konstitusi sampai pada klaim masyrakat adat (Hasil wawancara dengan masyarakat).

Hal ini menunjukkan secara jelas bahwa program kemitraan yang di tawarkan oleh Kementerian Kehutanan melalui Dinas Kehutanan belum mampu merubah paradigma masyarakat dalam menjaga dan melestarikan hutan secara bersama melalui kemitraan. Kondisi lain juga diperparah dengan tidak didukung oleh komitmen yang kuat dari masingmasing pihak sebagai pelaksana kebijakan kemitraan pengelolaan hutan di Register 45 (Syahza, 2009).

Hubungan yang terjadi antara civil society, pemerintah dan atau sektor swasta dalam rangka mencapai suatu tujuan kemitraan haruslah didasarkan pada prinsip kepercayaan, kesetaraan, dan kemandirian (Slamet Agus Purwanto, Sumartono, 2013). Berdasar pada pengertian di atas, kemitraan pengelolaan hutan merupakan pelaksanaan pengelolaan hutan yang dilakukan oleh badan usaha yang merupakan kolaborasi antara Pemerintah, Perusahaan dan Masyarakat serta unsur pendukung dengan segala hak dan kewajiban berdasarkan perjanjian yang disepakati

Dinas Kehutanan sebagai penanggung jawab akhirnya harus disibukkan dengan membangun struktur kepengurusan yang baru setelah ditarik ke Provinsi. PT. Silva Inhutani dan Masyarakat lebih tertarik untuk mengurusi tanaman semusim karena lebih menguntungkan. Pada akhirnya manfaat kebijakan kemitraan ini hanya sebagai peredam konflik dan jika tidak ada tindak lanjutnya maka suatu saat nanti konflik pasti akan terjadi kembali

Pasal 33 Undang-undang Dasar 1945 pada dasarnya telah mengamanatkan agar penguasaan negara atas hutan secara bersama-sama juga harus mengakomodasi berbagai kepentingan kelompok. Kepentingan tersebut tidak hanya perusahaan sebagai pemegang Hak Guna Usaha hutan tetapi juga kepentingan kelompok petani dan masyarakat sekitar hutan. Oleh sebab itu, seluruh masyarakat yang berada di sekitar hutan khususnya kawasan hutan Register 45 Kabupaten Mesuji berhak atas pengelolaan dan pemanfaatan hutan demi kehidupan masyarakat sekitar hutan.

Pengelolaan bersama melalui kemitraan ini ternyata belum mampu memberikan dampak yang baik bagi perusahaan dan masyarakat. Naskah perjanjian tersebut akhirnya hanya menjadi naskah perjanjian yang tidak mengikat jika melihat kurangnya komitmen dari kedua belah pihak. Sejauh ini manfaat yang paling kentara dari kemitraan pengelolaan hutan ini 


\section{Jurnal Ilmu Pemerintahan: Kajian Ilmu Pemerintahan dan Politik Daerah, 3 (2), Oktober 2018 - 196 \\ Andrialius Feraera1) *, Nandang Alamsah D²), Neneng Yani Yuningsih ${ }^{3)}$}

adalah diakuinya masyarakat secara legal sebagai masyarakat mitra. Artinya keberadaan mereka di Register 45 adalah sah berlandaskan hukum (Effendi, 2007).

Manfaat selanjutnya dari kemitraan pengelolaan hutan ini adalah meredam konflik pengelolaan hutan yang kerap terjadi di kawasan Register 45. Akan tetapi dampak baru yang muncul adalah konflik antara masyarakat yang setuju dan masyarakat yang menolak kemitraan pengelolaan hutan. Mengingat masih banyak masyarakat yang menolak untuk ikut dalam kemitraan pengelolaan hutan ini. Potensi konflik yang kemungkinan muncul lagi adalah konflik antara kelompok mitra dengan masyarakat sekitar Register 45 di mana ada kecemburuan sosial yang dirasakan oleh masyarakat sekitar hutan. Masyarakat sekitar hutan melihat bahwa masyarakat perambah diberikan akses untuk mengelola hutan sementara masyarakat sekitar hutan yang sah dan diakui oleh Pemerintah Kabupaten Mesuji tidak diberikan akses yang sama (Purnomo, 2009).

Dari sisi ekonomi, kemitraan pengelolaan hutan ini belum mampu meningkatkan produksi perusahaan dan meningkatkan kesejahteraan masyarakat. Dengan di aturannya lahan yang digarap yaitu maksimal $2 \mathrm{Ha}$ ternyata membuat beberapa kelompok masyarakat mengalami penurunan penghasilan. Pasalnya mereka biasanya menggarap lebih dari 2 Ha yang ditanami tanaman semusim seperti singkong. Lebih lanjut, pohon akasia memiliki masa panen yang lebih lama yaitu minimal 5 tahun sehingga masyarakat baru dapat merasakan keuntungan dari kemitraan pengelolaan hutan ini setelah 5 tahun realisasi kemitraan. Masa 5 tahun tersebut dapat tercapai jika tanaman tersebut di dirawat dengan baik.

PT. Silva Inhutani kemudian mengijinkan masyarakat untuk melakukan tanaman tumpang sari dengan tanaman semusim. Tujuannya adalah untuk tetap menjaga perekonomian masyarakat. Tetapi dengan tidak adanya bimbingan dan perhatian yang baik dari Pemerintah Daerah dan PT. Silva Inhutani khususnya maka kemungkinan lima tahun ke depanpun tidak akan mampu meningkatkan penghasilan petani. Pasalnya saat ini banyak tanaman akasia yang tidak dapat tumbuh dan tidak ditanami kembali. Masyarakat lebih tertarik menanam singkong dibandingkan pohon akasia. Padahal menanam singkong di kawasan hutan Register 45 adalah hal yang bertentangan dengan HGU Register 45.

Selain melakukan pembinaan di bidang teknologi, PT Silva Inhutani sebagai pemegang HGU Register 45 seharusnya juga membangun kerja sama dengan Pemerintah Daerah, Kepolisian, Perguruan Tinggi dan juga lembaga lain. Kerja sama ini akan meningkatkan hubungan, keamanan dan keahlian para petugas di lapangan. Pola kemitraan ini adalah dapat dikatakan sebagai strategi politik dalam pengelolaan hutan. Strategi ini harus benar-benar rapi dan strategis agar tidak terjadi pemborosan biaya, 


\section{Jurnal Ilmu Pemerintahan: Kajian Ilmu Pemerintahan dan Politik Daerah, 3 (2), Oktober 2018 - 197 \\ Andrialius Feraera1) *, Nandang Alamsah D²), Neneng Yani Yuningsih ${ }^{3)}$}

hasil yang tidak maksimal dan memunculkan potensi konflik baru.

\section{SIMPULAN DAN SARAN}

\section{Simpulan}

Beradasarkan Implementasi Kebijakan kemitraan pengelolaan hutan Register 45 meliputi identifikasi perambah dan sosialisasi, membangun kesepakatan dan pelaksanaan kemitraan. Dalam pelaksanaanya kemitraan ini tidak berjalan sebagaimana yang diharapkan (implementation gap).

Disisi lain faktor yang mendukung implementasi kebijakan kemitraan pengelolaan dalam dimensi struktur manajemen kebijakan adalah faktor sumber dana dan adanya teori pendukungnya. Selanjutnya, yang menjadi faktor penghambat pelaksanaan kemitraan pengelolaan yang termasuk dalam struktur manajemen kebijakan adalah kejelasan dan konsistensi, dasar hukum, perekrutan pejabat pelaksana serta Keterbukaan Kepada Pihak Luar. Faktor di luar peraturan ini menjadi faktor penghambat yang sangat dominan dalam pelaksanaan kemitraan pengelolaan hutan Register 45 meliputi kondisi sosial dan keamanan, minimnya dukungan publik, sikap masyarakat dan hilangnya komitmen dari pejabat pelaksana.

\section{Saran}

Demi mendukung kemitraan pengelolaan Hutan Register 45 ini maka pertama Pemerintah Daerah seharusnya mengeluarkan Peraturan Daerah mengenai kemitraan Pengelolaan Hutan
Register 45 agar Kemitraan ini memiliki kekuatan hukum yang kuat. Kedua, Dinas Kehutanan diharapkan segera menyelesaikan struktur pengurusan dan menunjuk penanggung jawab kemitraan pengelolaan hutan Register 45 agar sosialisasi intensif dan pembinaan dapat segera dilakukan. Dinas Kehutanan juga perlu meningkatkan keterlibatan Pemerintah Daerah Kabupaten, LSM, Perguruan Tinggi dan Kepolisian serta lembaga lain untuk mendukung pelaksanaan kemitraan ini.

Ketiga, Perusahan sebaiknya memberikan contoh yang baik kepada masyarakat dimana tidak lagi menanam tanaman semusim seperti singkong tetapi fokus pada tanaman keras sesuai dengan Hak Guna Usahanya. Keempat, Masyarakat yang telah setuju kemitraan seharusnya bersikap lebih kooperatif dengan mematuhi setiap perjanjian yang telah di tandatangani. Sementara itu, untuk masyarakat yang menolak kemitraan seharusnya menghormati pilihan masyarakat yang bermitra dan tidak saling mengganggu satu sama lain.

\section{DAFTAR PUSTAKA}

Adnan, H., Berliani, H., Hardiyanto, G., \& Sakti, D. (2015). Pemberdayaan Masyarakat melalui Kemitraan Kehutanan.

Ansell, C., \& Gash, A. (2007). Collaborative Governance in Theory and Practice Downloaded from. https://doi.org/10.1093/jopart/m um032

Effendi, R. (2007). Kajian pola-pola pemberdayaan masyarakat sekitar hutan produksi dalam mencegah illegal logging. Forda-Mof.Org, 4(4), 319-340. 
Jurnal Ilmu Pemerintahan: Kajian Ilmu Pemerintahan dan Politik Daerah, 3 (2),

Oktober 2018 - 198

Andrialius Feraera1) *, Nandang Alamsah D²), Neneng Yani Yuningsih ${ }^{3)}$

Hakim, I. (2009). Kajian Kelembagaan Dan Kebijakan Hutan Tanaman Rakyat: Sebuah Terobosan Dalam Menata Kembali Konsep Pengelolaan. Forda-Mof.Org, 6(1), 27-41.

KJ Ferdian. (2017). Model Resolusi Konflik Kawasan Register 45 Mesuji Lampung Berbasis Hutan Tanaman Rakyat. Ejournal.Undip.Ac.Id, 8(1), 92-102.

Lewis, S. C. (2015). Qualitative inquiry and research design: Choosing among five approaches. Journals.Sagepub.Com.

Lexy, J., \& Moleong. (2004). Pengantar Metodologi Penelitian.

Mazmanian, D. A., \& Sabatier, P. A. (1989). Implementation and public policy: with a new postscript. University Press of America.

Purnomo, H. (2009). Model dinamika sistem untuk pengembangan alternatif kebijakan pengelolaan hutan yang adil dan lestari. Cifor.Org.

Slamet Agus Purwanto, Sumartono, M. M. (2013). Implementasi Kebijakan Program Keluarga Harapan (PKH) Dalam Memutus Rantai Kemiskinan (Kajian di Kecamatan Mojosari Kabupaten Mojokerto).

Wacana.Ub.Ac.Id, 16(2), 79-89.

Syahza, A. (2009). Percepatan

pemberdayaan ekonomi masyarakat pedesaan dengan model agroestate berbasis kelapa sawit. Repository.Unri.Ac.Id.

Wahab, O. (n.d.). Gerakan Aktif Tanpa Kekerasan: Sebuah Transformasi Perjuangan Masyarakat (Kasus Masyarakat Moro-Moro Register 45 Mesuji Lampung). Journal.Ugm.Ac.Id.

Weiss, C. (n.d.). Methods for studying programs and policies. WikiDevel.Sugarlabs.Org.

\section{Profile Penulis}

Andrialius Feraera adalah mahasiswa Pascasarjana Ilmu Pemerintahan FISIP UNPAD dan telah menyelesaikan studinya pada tahun 2017.

Prof. Dr. H. Nandang Alamsah Deliarnoor, S.H., M.Hum adalah Dosen Ilmu Pemerintahan FISIP UNPAD.

Dr. Neneng Yani Yuningsih, S.IP., M.Si adalah Dosen Ilmu Pemerintahan FISIP UNPAD. 